DOI: 10.12731/2218-7405-2018-3-16-27

UDC 378.1

\title{
THE PECULIARITIES OF FOREIGN LANGUAGE TRAINING OF TECHNICAL UNIVERSITY STUDENTS IN CONDITIONS OF COMPETENCE APPROACH
}

\section{Bagateeva A.O., Ryseva Yu.V., Vasilyeva A.A., Garaeva R.S.}

The article deals with the concepts of "communicative competence" and "foreign language communicative competence". The research is based on such methods as observation, analysis, and modeling method. The article presents the author's interpretation of the concept of foreign language communicative competence of students from the position of competence and system approaches. The authors give the component composition of foreign language communicative competence from the point of view of various researchers, define its structural elements. On the basis of the analysis, the model of modular technology of foreign language training of technical university students is constructed, the characteristic of its structural components is given, and also the results of its implementation in the process of foreign language training technical university students are described. The use of modular technology in foreign language training of technical university students allows to obtain a high level of foreign language communicative competence. The model of modular technology of foreign language training of technical university students is developed. The results of the study can be applied to the foreign language training of students not only technical universities, but others as well.

Keywords: foreign language training; foreign language communicative competence; competence approach; modular technology of education.

\section{ОСОБЕННОСТИ ИНОЯЗЫЧНОЙ ПОДГОТОВКИ СТУДЕНТОВ ТЕХНИЧЕСКОГО ВУЗА В УСЛОВИЯХ КОМПЕТЕНТНОСТНОГО ПОДХОДА}

\section{Багатеева А.О., Рысева Ю.В., Васильева А.А., Гараева Р.С.}

В статье рассматриваются понятия «коммуникативная конкуренция» и «иноязычная коммуникативная компетентность». В 
основе исследования лежат такие методы, как наблюдение, анализ и моделирование. В статье представлена авторская интерпретация понятия иноязычной коммуникативной компетентности студентов с позиции компетентностного и системного подходов. Авторами представлен компонентный состав иноязычной коммуникативной компетенции с точки зрения различных исследователей, определень его структурные элементы. На основе проведенного анализа была построена модель модульной технологии иноязычной подготовки студентов технического вуза, дана характеристика ее структурных компонентов, а также описаны результаты ее реализации в процессе иноязычной подготовки студентов технического вуза. Использование модульной технологии в обучении студентов технических вузов иностранному языку позволяет получить высокий уровень иноязычной коммуникативной компетентности. Разработана модель модульной технологии иноязычной подготовки студентов технического вуза. Результаты исследования могут быть применены к иноязычной подготовке студентов не только технических, но и других вузов.

Ключевые слова: иноязычная подготовка; иноязычная коммуникативная компетентность; компетентностный подход; модульная технология обучения.

\section{Introduction}

The article is devoted to the actual issue of foreign language training in the conditions of scientific and technical cooperation, internship opportunities abroad, work with technical documentation in foreign languages. The subject of the analysis is foreign language training of students in terms of competence-based approach [7]. The authors aim is to reveal the peculiarities of foreign language training in a technical university [12], identify the existing problems, suggest ways of solving them. In modern conditions of expansion of international relations, a high level of foreign language training of students studying in technical universities $[13,14]$ becomes absolutely important. Moreover, restructuring of the entire system of foreign language education is closely connected with the transition to a two-level education (bachelor's and 
master's) and implementation of the competence approach. Such trends in education [4] require intensive enrichment of the process of formation of foreign language communicative competence (FLCC) as a result of foreign language training of both new content and new methods $[1,2]$. Thus, at the present stage of Russia's development in the context of social, political, economic and sociocultural changes, there is every reason to consider foreign language training as a necessary condition of successful professional activity of future graduates from technical universities - potential participants of intercultural dialogue, underlining the need of foreign language training of technical university students [3]. However, teaching foreign language with the professional orientation, as well as the level of FLCC is not high enough which is evident by the shortage of specialists with the high level of the developed FLCC [9]. To achieve high level of FLCC, it is necessary to use innovative approaches to foreign language teaching in addition to traditional ones [10]. There are various technologies used in language training of technical university students [11]. The conducted analysis has shown that there is some experience of training technical university students in the aspect of foreign language training and modular technology is considered the most effective [15]. The result of high-level foreign language training should be the personal development of students, the desire to deepen their professional knowledge by means of foreign language [6]. To achieve this goal, it is necessary to develop the modular technology model of foreign language training of technical university students and implement it in the educational process. To verify the effectiveness of the developed model, the experimental work was carried out on the base of the Automotive Department of Naberezhnye Chelny Institute (branch) of Federal State Autonomous Educational Institution "Kazan (Volga region) Federal University" where 250 students took part in the experiment who were divided into control and experimental groups [8].

\section{Methods}

The detailed analysis in theoretical aspect of content and component composition of FLCC has shown that researchers define it in various 
ways: for instance, FLCC is considered as possession of oral and written communication (W. Hutmacher) [15], as an individual's ability (I.I. Galimzyanova, N.I. Gez) [9, 10], as a component of professional training (R.P. Milrud) [11]. There is no totally accepted set of the FLCC components, but it is possible to define some universal components - linguistic (language), speech, sociocultural, strategic (compensatory), discursive, educational, intercultural competences [5].

Due to the system-based and competence-based approaches, the authors of the article suggest their own definition to the FLCC concept and offer the set of competencies which are included into the FLCC.

\section{Results}

The authors' definition of the FLCC concept is the following: it as an integrative characteristic of foreign language training that helps to communicate in the sphere of future professional activity and increase professional level by means of foreign languages. According to the definition, we offer the following set of competencies are included into the FLCC: linguistic competence, speech competence, sociocultural competence, strategic competence, self-educational competence $[3,8]$.

- The linguistic competence, which involves the ability to understand and apply units of foreign language in accordance with the professional area: its invariant part is possession of knowledge of the basic phonetic, lexical, grammatical, derivational phenomena; the variable part presupposes the possession of professional (automotive) vocabulary;

- The speech competence, which reflects the required level of proficiency in communication technology: its invariant part includes the ability to understand and generate foreign-language utterances in communicative processes; the variable part involves the ability to understand foreign-language texts and use various types of communications in the field of service, maintenance, cars sales and technological equipment;

- The sociocultural competence, which involves the ability to understand and use linguistic forms in accordance with the situation: 
the invariant part is determined by the ability to social interaction in accordance with the accepted moral and legal norms, standards, culture and traditions of the foreign-speaking countries; the variable part consists of knowledge of sociocultural information about the automotive industry, the sphere of car service in the countries of studied language;

- The strategic competence, which includes the ability to compensate the lack of knowledge of foreign language; the invariant part is based on the ability to use basic phrases and clichés, synonyms when solving professional problems in foreign language; the variable part is the ability to get out of the situation with a deficit of language structures with representatives of auto companies, suppliers of spare parts and materials, using phrases and clichés of professional vocabulary;

- The self-educational competence, which involves the motivation to further study of foreign languages, for self-education: the invariant part includes ability to study foreign languages and cultures independently; the variable part determines the ability to use foreign language opportunities for further professional growth [8].

The results of implementing the developed model are the following: the level of foreign language training increased significantly in the experimental groups, which confirms the effectiveness of the implemented model of foreign language training of technical university students in the experimental groups; the motivation of students to learn foreign language significantly increased in the experimental groups; activity and interest in learning foreign language were not observed in the control groups; moreover, students of the experimental groups reached a high level of reflection and ability to self-development; in the control groups this figure remained at the initial low level [8].

\section{Discussion}

There are various technologies in the practice of foreign language training of technical university students such as project technology, case-technology, technology of contextual education, modular technol- 
ogy, etc. However, in our opinion, the use of modular technology in the foreign language training of technical university students has a number of advantages: the content of education is based on the activity basis and is presented in separate blocks; the clear structure of the educational material allows students of technical orientation with logical, systemic thinking to improve the level of foreign language training more effectively.

A model of modular technology of foreign language training of technical university students has been developed on the basis of FLCC structure, the main structural components of which are: theoretical and methodological unit; purposeful unit; content unit; process-technological unit and effective-evaluative unit. Together, the components of the developed model determine the achieved result that is a high level of foreign language training which is necessary for effective search of information from foreign sources and professional communication in a foreign language.

\section{Conclusions}

Nowadays the need for specialists with a high level of foreign language training for personal and professional communication is growing due to the intensive development of international cooperation and Russia's integration into the world community.

There are many technologies in language training of technical university students but due to the analysis the modular technology is considered to be the most effective in the aspect of foreign language training. Modular technology of foreign language training of technical university students is a specially organized process of foreign language learning to achieve a high level of FLCC development. The results of the experiment have proved the effectiveness of the developed model of modular technology of foreign language training of technical university students.

\section{Acknowledgements}

The work is performed according to the Russian Government Program of Competitive Growth of Kazan Federal University. 


\section{References}

1. Akhmetzyanova G.N. Vliyanie sotsialno-ekonomicheskih protsessov na sistemu nepreryivnogo professionalnogo obrazovaniya rabotnikov avtomobilnoy otrasli [The impact of socio-economic processes on the system of continuing professional education of employees of the mobile industry]. Kazan pedagogical journal. Kazan. 2010. No. 2 (80), pp. 11-17.

2. Akhmetzyanov G.N. Kompetentnostnyiy podhod k sisteme nepreryivnogo professionalnogo obrazovaniya pri podgotovke rabotnikov dlya avtomobilnoy otrasli [Competence approach to the system of continuous professional education in preparing workers for the automotive industry]. Bulletin of Kazan technological University. 2009. No. 4, pp. 349-355.

3. Bagateeva A.O., Akhmetzyanova G.N., Valeeva N.Sh. K probleme formirovaniya inoyazyichnoy kommunikativnoy kompetentnosti bakalavrov $v$ tehnicheskom vuze [To the problem of formation of foreign language communication catelnau competence of bachelors in a technical College]. Bulletin of Kazan technological University. 2014. No. 11. Vol. 17, pp. 251-253.

4. Bagateeva A.O., Shaidullina A.R., Ishmuradova A.M., etc. The Implementation of the Cluster Approach in the Regional System of Vocational Education. Review of European Studies. 2015. Vol. 7. №4, pp. 66-72.

5. Bagateeva A.O. The Methodological Approaches Of The Process Of Forming Foreign Language Competence For Future Specialists Of Technical Universities. The materials of the $2^{\text {nd }}$ International Scientific Conference «Science and Education». Germany, Munich. 2012, pp. 200-204.

6. Bagateeva A.O. , Ishmuradova A.M., Yevgrafova O.G., Derdizova F.V., Maksimova E.V., Romazanova O.V., Fassakhova G.R. The model of formation of Foreign-Language skills of the students in Self-Learning activities. Asian Social Science. 2014. Vol. 11. Issue 1, 2, pp. 162-168.

7. Bagateeva A.O., Akhmetzyanova G.N. Psychoeducational Support Of Foreign Language Training In Higher School. Modern Journal of Language Teaching Methods (MJLTM) Vol. 7, Issue. 12, December (2017) 018-022, pp. 183-187.

8. Bagateeva A.O., Akhmetzyanova G.N. Modular Technology Of Foreign Language Training Of Technical University Students. Modern Journal 
of Language Teaching Methods (MJLTM) Vol. 7, Issue. 9.2, September (2017) 018-022, pp. 157-160.

9. Galimzyanova I. I. Pedagogicheskaya sistema formirovaniya inoyazyichnoy kommunikativnoy kompetentnosti buduschih inzhenerov [Pedagogical system of formation of foreign language communicative competence of future engineers]: dis. ... doc. of ped. sciences: 13.00.08. Kazan. 2009. 384 p.

10. Gez N.I. Formirovanie kommunikativnoy kompetentsii kak ob'ekt zarubezhnyih metodicheskih issledovaniy [Formation of communicative competence as an object of foreign methodological research]. Foreign languages practitioner of engineering profile at school. 1985. No. 2, pp. 17-24.

11. Milrud R.P. Kompetentnost v izuchenii inostrannogo yazyika [Competence in foreign language learning]. Foreign languages at school. 2004. No. 7, pp. 30-36.

12. Ryseva Yu.V., Kalashnikova M.M. Realizatsiya idey problemnogo obucheniya $v$ vuze na urokah angliyskogo yazyika [Implementing the ideas of problem based learning in high school English lessons]. Problem-based learning in the modern world VIth International Makhmutov reading: collection of articles. Edited by E.E. Merzon, V.L. Vinogradov, R.F. Ahtarieva, V.A. Martyinova. 2016, pp. 444-450.

13. Ryseva Yu.V. Formirovanie tvorcheskoy pozitsii studentov tehnicheskogo vuza posredstvom inostrannogo yazyika [Formation of the creative position of students of technical university by means of a foreign language]. Final scientific conference of 2015, collection of reports of the final scientific conference of the faculty: in 3 parts. "Kazan (Volga region) Federal University", Naberezhnye Chelny Institute (branch); Executive editor, L.A. Simonova. 2015, pp. 290-293.

14. Ryseva Yu.V., Maksimova E.V., Ishmuradova A.M., Kalashnikova M.R. Realizatsiya usloviy formirovaniya kommunikativnoy kompetentsii studentov v protsesse izucheniya inostrannyih yazyikov v tehnicheskom vuze [Implementation of the conditions of formation of communicative competence of students in the process of learning foreign languages in a technical university]. Modern research of social problems. 2015. No. 3 (47), pp. 121-132.

15. Hutmacher W. Key competencies for Europe. Report of the Symposium Berne, Switzerland 27-30 March, 1996. Council for Cultural Co-opera- 
tion (CDCC) a Secondary Education for Europe. Strasburg, 1997. Secondary Education for Europe Strsburg, 1997. 211 p.

\section{Список литературы}

1. Ахметзянова Г.Н. Влияние социально-экономических процессов на систему непрерывного профессионального образования работников автомобильной отрасли // Казанский педагогический журнал. Казань. 2010. №2 (80). С. 11-17.

2. Ахметзянова Г.Н. Компетентностный подход к системе непрерывного профессионального образования при подготовке работников для автомобильной отрасли // Вестник Казанского технологического университета. Казань. 2009. №4. С. 349-355.

3. Багатеева А.О. К проблеме формирования иноязычной коммуникативной компетентности бакалавров в техническом вузе / А.О. Багатеева, Г.Н. Ахметзянова, Н.Ш. Валеева // Вестник Казанского технологического университета. 2014. №11. Т.17. С. 251-253.

4. Bagateeva A.O. The Implementation of the Cluster Approach in the Regional System of Vocational Education / A.O. Bagateeva, A.R. Shaidullina, A.M. Ishmuradova, etc. // Journal «Review of European Studies». 2015. Vol. 7. №4, pp. 66-72.

5. Bagateeva A.O. The Methodological Approaches Of The Process Of Forming Foreign Language Competence For Future Specialists Of Technical Universities // Материалы второй международной научной конференции «Наука и образование». Германия, Мюнхен. 2012. C. 200-204.

6. Bagateeva A.O. The model of formation of Foreign-Language skills of the students in Self-Learning activities / A.O. Bagateeva, Ishmuradova A.M., Yevgrafova O.G., Derdizova F.V., Maksimova E.V., Romazanova O.V., Fassakhova G.R. // Journal «Asian Social Science». 2014. Vol. 11. Issue 1, 2, pp. 162-168.

7. Bagateeva A.O. Psychoeducational Support Of Foreign Language Training In Higher School / A.O. Bagateeva, G.N. Akhmetzyanova // Modern Journal of Language Teaching Methods (MJLTM) Vol. 7, Issue 12, December (2017) 018-022, pp. 183-187. 
8. Bagateeva A.O. Modular Technology Of Foreign Language Training Of Technical University Students / A.O.Bagateeva, G.N.Akhmetzyanova // Modern Journal of Language Teaching Methods (MJLTM) Vol. 7, Issue 9.2, September (2017) 018-022, pp. 157-160.

9. Галимзянова И.И. Педагогическая система формирования иноязычной коммуникативной компетентности будущих инженеров: дис. ... д-ра пед. наук: 13.00.08. Казань, 2009. 384 с.

10.Гез Н.И. Формирование коммуникативной компетенции как объект зарубежных методических исследований // Иностранные языки специалиста инженерного профиля в школе. 1985. № 2. С. 17-24.

11. Мильруд Р.П. Компетентность в изучении иностранного языка // Иностранные языки в школе. 2004. № 7. С. 30-36.

12. Рысева Ю.В. Реализация идей проблемного обучения в вузе на уроках английского языка / М.М. Калашникова, Ю.В. Рысева // Проблемное обучение в современном мире VI Международные Махмутовские чтения: сборник статей. Под редакцией: Е.Е. Мерзон, В.Л. Виноградова, Р.Ф. Ахтариевой, В.А. Мартыновой. 2016. С. $444-450$.

13.Рысева Ю.В. Формирование творческой позиции студентов технического вуза посредством иностранного языка // Итоговая научная конференция 2015 года сборник докладов итоговой научной конференции профессорско-преподавательского состава: в 3 частях. ФГАОУ ВПО «Казанский (Приволжский) федеральный университет», Набережночелнинский институт (филиал); Ответственный редактор Л.А. Симонова. 2015. С. 290-293.

14.Рысева Ю.В. Реализация условий формирования коммуникативной компетенции студентов в процессе изучения иностранных языков в техническом вузе / Э.В. Максимова, А.М. Ишмурадова, М.Р. Калашникова, Ю.В. Рысева // Современные исследования социальных проблем (электронный научный журнал). 2015. № 3 (47). C. 121-132.

15.Hutmacher W. Key competencies for Europe // Report of the Symposium Berne, Switzerland 27-30 March, 1996. Council for Cultural Co-operation (CDCC)a Secondary Education for Europe. Strasburg, 1997 / Secondary Education for Europe Strsburg, 1997. 211 p. 


\section{DATA ABOUT THE AUTHORS}

Bagateeva Angelina Olegovna, Assistant Professor of Foreign Languages Department, $\mathrm{PhD}$ in Pedagogic Sciences

Naberezhnye Chelny Institute of Kazan (Volga region) Federal University

68/19, Mira Ave., Naberezhnye Chelny, Republic of Tatarstan, 423800, Russian Federation

angel803@yandex.ru

ORCID: 0000-0002-2884-0322

Scopus Author ID: 56440163500

Ryseva Yuliya Viktorovna, Associate Professor of Foreign Languages Department, $\mathrm{PhD}$ in Pedagogic sciences

Naberezhnye Chelny Institute of Kazan (Volga region) Federal University

68/19, Mira Ave., Naberezhnye Chelny, Republic of Tatarstan, 423800, Russian Federation

j-rys@mail.ru

Vasilyeva Aida Alegovna, Associate Professor of Foreign Languages Department, PhD in Pedagogic Sciences

Niznnekamsk Institute of Chemical Technology (the branch of Kazan National Research Technological University)

47, Stroiteley Ave., Nizhnekamsk, Republic of Tatarstan, 423578, Russian Federation

v.aida@inbox.ru

Garaeva Rimma Salavatovna, Associate Professor of Foreign Languages Department, $\mathrm{PhD}$ in Pedagogic Sciences

Niznnekamsk Institute of Chemical Technology (the branch of Kazan National Research Technological University)

47, Stroiteley Ave., Nizhnekamsk, Republic of Tatarstan, 423578, Russian Federation mirka_81@mail.ru 


\section{ДАННЫЕ ОБ АВТОРАХ}

Багатеева Ангелина Олеговна, ассистент кафедры иностранных языков, кандидат педагогических наук Набережночелнинский институт Казанского (Приволюского) федерального университета пр-кт Мира, 68/19, г. Набережные Челны, Республика Татарстан, 423800, Российская Федерация angel803@yandex.ru

Рысева Юлия Викторовна, доцент кафедры иностранных языков, кандидат педагогических наук Набережночелнинский институт Казанского (Приволжского) федерального университета пр-кт Мира, 68/19, г. Набережные Челны, Республика Татарстан, 423800, Российская Федерация j-rys@mail.ru

Васильева Аида Алеговна, доцент кафедры иностранных языков, кандидат педагогических наук Нижнекамский химико-технологический институт ФГБОУ ВО КНИТУ

пр-кт Строителей, 47, г. Нижнекамск, Республика Татарстан, 423578, Российская Федерация v.aida@inbox.ru

Гараева Римма Салаватовна, доцент кафедры иностранных языков, кандидат педагогических наук Нижнекамский химико-технологический институт ФГБОУ ВО КНИТУ

пр-кт Строителей, 47, г. Нижнекамск, Республика Татарстан, 423578, Российская Федерачия mirka_81@mail.ru 